\title{
重度歯周疾患患者から分離した歯周ポケットにおける 病原酵素産生細菌の分布
}

\author{
井上純一福島 久典尾上孝利江龍多美子 \\ 上田雅俊* 山岡昭* 佐川 宽 典 \\ 大阪歯科大学細菌学教室 \\ （主任 : 佐川寛典教授） \\ *大阪歯科大学歯周病学講座 \\ (主任 : 山岡 昭教授) \\ (平成元年 12 月 21 日受付)
}

\section{Distribution of Enzymatically Pathogenic Bacteria from Periodontal Pocket in Advancing Periodontitis}

\author{
Jun-ichi INOUE, Hisanori FUKUSHIMA, Takatoshi ONOE, Tamiko ERYU, \\ Masatoshi UEDA*, Akira YAMAOKA* and Hirosuke SAGAWA \\ Department of Bacteriology, Osaka Dental University \\ 5-31, Otemae 1-Chome, Chuo-ku, Osaka 540, Japan \\ (Chief : Prof. Hirosuke SAGAWA) \\ *Department of Periodontology, Osaka Dental University \\ (Chief : Prof. Akira YAMAOKA)
}

Production of 9 enzymatic activities of 527 strains freshly isolated from periodontal pockets in advancing periodontitis were investigated. Of these isolates, two strains showed lecithinase activity on egg yolk agar plate. Collagenase, plasmin and lipase were produced by 28 strains, 26 strains and 22 strains, respectively.

Two lecithinase-producing strains were identified as Bacteroides intermedius. Nineteen strains of $B$. intermedius and 1 strain of Fusobacterium species produced lipase on egg yolk agar plate. All of the 28 collagenase-producing strains were $B$. gingivalis. $B$. gingivalis (20 strains) and non black-pigmented Bacteroides (6 strains) showed plasmin activity. These results indicate that Bacteroides species, mainly $B$. gingivalis and $B$. intermedius may exert an important influence on the exacerbation of the disease.

Key words : Periodontal pocket, Bacteria, Enzymatic activities

要旨：6名の重度歯周疾患患者の歯周ポケットから分離した 527 株の細菌を用いて, lecithinase, collagenase, plasmin, lipase, coagulase, $\beta$-lactamase, hyaluronidase, chondroitin sulfatase および DNase 活性について検索 した結果, 以下の成績を得た。

1. Lecithinase 産生株は 2 株検出され, 2 株とも，Bacteroides intermedius であった。本菌が分離されたポケッ ト内での分布比率は $2 \%$ であった。

本論文の一部は, 第 29 回秋季歯周病学会総会 (1986 年 11 月 20 日) および第 60 回日本細菌学会総会（1987 年 3 月 28 日）におい て発表した。 
2. Collagenase 産生株は, 28 株であり，いずれも, Bacteroides gingivalis と同定された。本菌は 4 名の患者から 分離され, その分布比率は 1.2〜 14.9\% であった。また, plasmin 産生株は 26 株であり, 4 名の患者から分離され た。そのうち，20株は B. gingivalis で，分布比率は 1.2〜 $13.9 \%$ であった。

3. Lipase 産生株は 22 株検出され, 19 株が B. intermedius であった。

4. 他の酵素を産生する菌株は検出されなかった。

以上の結果から，直接的な病原因子と考えられる lecithinase, collagenase, plasmin, lipase などの酵素産生株の 主体は Bacteroides であると考えられる。

索引用語 : 歯周ポケット, 細菌, 酵素活性

\section{緒言}

歯周ポケット内細菌叢の検索では, Bacteroides gingivalis を初めとする black-pigmented Bacteroides (BPB) が優勢であり ${ }^{1,2)}$, それらの細菌が歯周炎の病原菌として 注目されている

我々は重度および中等度歯周疾患患者の歯周ポケット 内細菌叢の検索において偏性嫌気性グラム陰性桿菌ばか りでなく,グラム陽性桿菌もかなり高い比率で分離され ることを明らかにしている14 16)。さらに, 歯周ポケット 内から分離した主要細菌に対し API ZYM を用いて 19 種類の酵素活性の認められる株を検索したところ, 歯周 病原性と関連深い trypsin, chymotrypsin, N-acetyl- $\beta-$ glucosaminidase, acid phosphatase および alkaline phosphatase 産生株は主として Bacteroides であった。 同時に, Actinomyces, Peptostreptococcus, Streptococcus などのグラム陽性菌が優勢であった ${ }^{17) 。}$

そこで, 本実験では重度歯周疾患患者の歯周ポケット から分離した細菌（527 株）が, 歯周病原性と関連が深 いと考えられる lecithinase, collagenase, plasmin, lipase, coagulase, $\beta$-lactamase, hyaluronidase, chondroitin sulfatase および DNase などの酵素活性を有す るかどうかを検討し，それらの酵素産生株を同定した。

\section{実験材料および方法}

\section{1. 被験者および供試菌株}

大阪歯科大学附属病院歯周病科に来院した 6 名の重度 歯周疾患患者から分離した 527 株を実験に使用した。被 験者 $\mathrm{A} \sim \mathrm{F}$ の臨床診查結果は既に報告している ${ }^{17)}$ 。また， 分離細菌の同定方法は, 既報告どおりに行った ${ }^{14 \sim 17) 。 ~}$

\section{2. 酵素活性の測定法}

酵素活性は lecithinase, collagenase, plasmin, lipase, coagulase, $\beta$-lactamase, hyaluronidase, chondroitin sulfatase および DNase の 9 種類について，以下の方法 で検討した。

1) Lecithinase 活性

LD-egg yolk agar ${ }^{18)}$ に供試菌を接種し，7 日間嫌気 培養後, 周囲に淡黄乳白色の不透明帯 (乳光反応) を生 じた集落を lecithinase 産生株とした（Fig. 1-a)。

2) Collagenase 活性

Hemin $5 \mathrm{mg} / \mathrm{m} l$, L-cystine $400 \mathrm{mg} / \mathrm{m} l$ および vitamin $\mathrm{K}_{1} 50 \mu \mathrm{g} / \mathrm{m} l$ 加 trypticase soy broth (TSB, BBL, USA) に供試菌を接種後, 嫌気的に 7 日間培養し,コラゲノキッ ト LN-100巴（コラーゲン技術研修会，東京）を用いて 活性を検討した。

3) Plasmin 活性

供試菌を TSB に接種後, 嫌気的に 7 日間培養した。 培養菌液をフィブリン・プレート（北里研究所東京）に 滴下し，その周囲に透明帯が認められたものを陽性とし た。

4) Lipase 活性

LD-egg yolk agar ${ }^{18)}$ に供試菌を接種後, 嫌気的に 7 日閒培養後, 集落の表面や周辺に真珠様光沢をもつ菌株 を lipase 産生株とした（Fig. 1-b)。

5) Coagulase 活性

細菌学実習提要 ${ }^{19)}$ に記載されている試験管法で行っ た。

6) $\beta$-Lactamase 活性

供試菌を TSB に接種後, 嫌気的に 7 日間培養した菌 液に Nitrocefin（BBL, USA）を一滴添加する broth 法 で判定した。

7) Hyaluronidase および chondroitin sulfatase 活 性

Smith and Willett の方法 ${ }^{20)}$ によた。

8) DNase 活性

Jefferies の方法 ${ }^{21)}$ 用いた。 


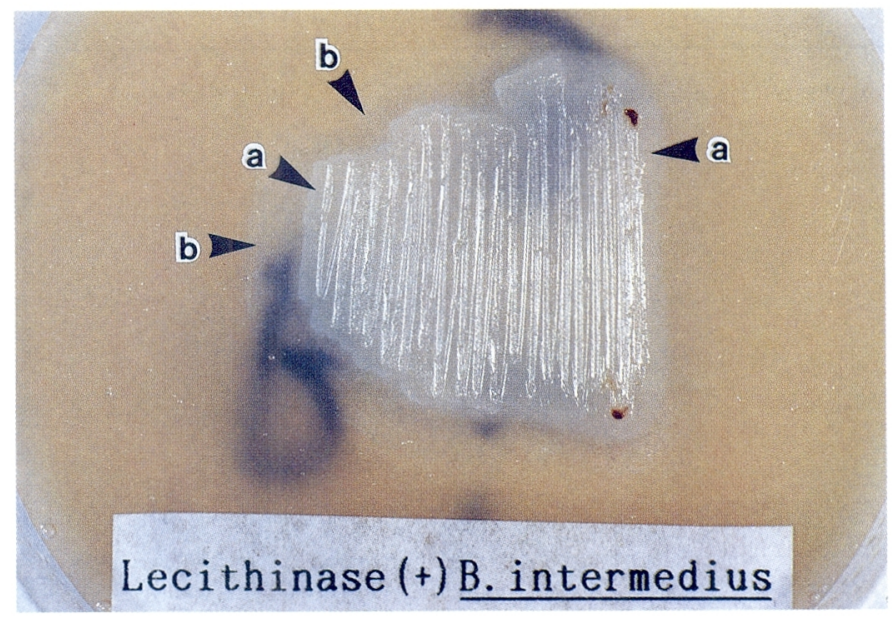

Fig. 1

Table 1 Proportional distribution of lecithinase producing bacteria

\begin{tabular}{ccccc}
\hline Enzyme & Patient & $\begin{array}{c}\text { Proportional } \\
\text { distribution }(\%)\end{array}$ & Bacteria & $\begin{array}{c}\text { Number } \\
\text { of isolates }\end{array}$ \\
\hline Lecithinase & F & 2.0 & $\begin{array}{c}\text { Bacteroides } \\
\text { intermedius }\end{array}$ & 2 \\
& A & $\frac{0}{0}$ & & \\
B & $\frac{0}{0}$ & \\
C & $\frac{0}{0}$ & \\
D & & \\
E &
\end{tabular}

\section{実験成績}

\section{Lecithinase 活性}

Lecithinase 産生株は $\mathrm{F}$ 症例で検出され，その分布比 率は $2.0 \%$ であり, 2 株の産生株はいずれもB. intermedius と同定された (Table 1)。

\section{Collagenase 活性および plasmin 活性}

Collagenase 活性および plasmin 活性の分布比率は,

Table 2 に示した。Collagenase 活性を有する菌株は 4 症例から 28 株分離され, すべて B. gingivalis であっ た。分布比率の範囲は 0 $14.9 \%$ であり, C 症例では全 分離菌の $14.9 \%$ (20 株) に collagenase 活性が認めら れた。

Plasmin 産生株は, 4 症例から検出され, 分布比率の 範囲は $0 \sim 13.9 \%$ で，合計 26 株分離された。そのうち， 20 株は B. gingivalis, 6 株が非黒色色素産生性 Bacteroides であった。C 症例では全分離菌の $13.9 \%$ (19株)に plasmin 産生株が認められ，そのうち，16株が B. gingivalis であった。

Table 3 は, collagenase および plasmin 産生株数と 同定結果を比較したものである。B. gingivalisのうち両 酵素活性を示した菌株は 20 株, collagenase 活性陽性で plasmin 活性陰性の菌株は 8 株であった。また，collagenase 活性陰性で plasmin 活性陽性の菌株は 6 株みら れ，以ずれも非黒色色素産生性の Bacteroides であった。

\section{Lipase 活性}

Lipase 産生株は, 4 症例から 22 株検出され, 19 株は B. intermedius, 1 株は Fusobacterium であったが, 2 株 は今回の同定法では同定できなかった。分布比率の範囲 は 0 9.9\%で，A の症例で最も多く認められた（Table 4)。

4. Coagulase, $\boldsymbol{\beta}$-lactamase, hyaluronidase, chondroitin sulfatase および DNase 活性

Coagulase, $\beta$-lactamase, hyaluronidase, chondroitin sulfatase および DNase 産生株は検出されなかった。 
Table 2 Proportional distribution of collagenase and plasmin-producing bacteria

\begin{tabular}{|c|c|c|c|c|}
\hline Enzyme & Patient & $\begin{array}{c}\text { Proportional } \\
\text { distribution }(\%)\end{array}$ & Bacteria & $\begin{array}{l}\text { Number } \\
\text { of isolates }\end{array}$ \\
\hline \multirow[t]{6}{*}{ Collagenase } & $\mathrm{A}$ & $\underline{3.0}$ & $\begin{array}{c}\text { Bacteroides } \\
\text { gingivalis }\end{array}$ & 3 \\
\hline & $\mathrm{C}$ & $\underline{14.9}$ & $\begin{array}{l}\text { Bacteroides } \\
\text { gingivalis }\end{array}$ & 20 \\
\hline & $\mathrm{E}$ & $\underline{1.2}$ & $\begin{array}{l}\text { Bacteroides } \\
\text { gingivalis }\end{array}$ & 1 \\
\hline & $\mathrm{F}$ & $\underline{4.9}$ & $\begin{array}{l}\text { Bacteroides } \\
\text { gingivalis }\end{array}$ & 4 \\
\hline & B & $\underline{0}$ & & \\
\hline & $\mathrm{D}$ & 0 & & \\
\hline \multirow[t]{6}{*}{ Plasmin } & A & $\underline{3.0}$ & $\begin{array}{l}\text { Bacteroides } \\
\text { gingivalis } \\
\text { sp. }\end{array}$ & $\begin{array}{l}1 \\
2\end{array}$ \\
\hline & C & $\underline{13.9}$ & $\begin{array}{l}\text { Bacteroides } \\
\text { gingivalis } \\
\text { sp. }\end{array}$ & $\begin{array}{r}16 \\
3\end{array}$ \\
\hline & $\mathrm{E}$ & 1.2 & $\begin{array}{l}\text { Bacteroides } \\
\text { gingivalis }\end{array}$ & 1 \\
\hline & $F$ & 3.7 & $\begin{array}{l}\text { Bacteroides } \\
\text { gingivalis } \\
\text { sp. }\end{array}$ & $\begin{array}{l}2 \\
1\end{array}$ \\
\hline & $\mathrm{B}$ & $\underline{0}$ & & \\
\hline & D & $\underline{0}$ & & \\
\hline
\end{tabular}

Table 3 Number of isolates produced collagenase and plasmin

\begin{tabular}{cccl}
\hline Collagenase & Plasmin & $\begin{array}{c}\text { Number } \\
\text { of isolates }\end{array}$ & Bacteria \\
\hline+ & + & 20 & Bacteroides gingivalis \\
+ & - & 8 & Bacteroides gingivalis \\
- & + & 6 & Bacteroides sp. \\
\hline
\end{tabular}

\section{考察}

歯周ポケットから分離された主要細菌がどのような酵 素活性を有し, その酵素産生株の分布比率を患者間で比 較検討することは歯周疾患増悪のメカニズムを解明する 上で重要である。

我々は先の実験で歯周ポケット内から分離した 527 株

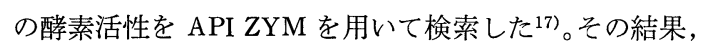
歯周組織に為害作用を及ぼすと推定される trypsin 産生 株は 28 株, chymotrypsin 産生株は 19 株, N-acetyl- $\beta$ - glucosaminidase 産生株は 62 株, acid phosphatase お よび alkaline phosphatase 産生株はそれぞれ 298 株と 268 株であった。それらの酵素産生株を同定した結果, B. gingivalis をはじめとする BPB が優勢であったが, 同時に Actinomyces, Peptostreptococcus および Streptococcus などのグラム陽性菌も優勢であり, BPB および これらのグラム陽性菌が歯周疾患の増悪に関与している 可能性を示唆した。

本実験では歯周ポケット内から分離した菌株 (527 株) を用いて，強い病原性を示すと考えられる lecithinase， collagenase, plasmin, lipase, coagulase, $\beta$-lactamase, hyaluronidase, chondroitin sulfatase および DNase 産 生性を検討した。

これらの酵素の中で, lecithinase 活性は細胞膜を構成 している lecithin を分解し, 直接, 宿主細胞を破壊する 酵素である。歯周ポケット内から，一人の被験者である が, $2 \%$ の割合で lecithinase 産生株がみられたことは産 生株の認められなかった歯周ポケットと比較した場合, 歯周疾患の増悪過程に差がある可能性が考えられる。 
Table 4 Proportional distribution of lipase producing bacteria

\begin{tabular}{|c|c|c|c|c|}
\hline Enzyme & Patient & $\begin{array}{c}\text { Proportional } \\
\text { distribution (\%) }\end{array}$ & Bacteria & $\begin{array}{l}\text { Number } \\
\text { of isolates }\end{array}$ \\
\hline \multirow[t]{8}{*}{ Lipase } & A & $\underline{9.9}$ & $\begin{array}{l}\text { Bacteroides } \\
\text { intermedius }\end{array}$ & 8 \\
\hline & & $\frac{1.0}{1.0}$ & $\begin{array}{l}\text { Fusobacterium } \\
\text { Not identified }\end{array}$ & 1 \\
\hline & $\mathrm{C}$ & $\overline{2.9}$ & $\begin{array}{l}\text { Bacteroides } \\
\text { intermedius }\end{array}$ & 4 \\
\hline & $\mathrm{E}$ & $\underline{3.7}$ & $\begin{array}{l}\text { Bacteroides } \\
\quad \text { intermedius }\end{array}$ & 3 \\
\hline & F & $\underline{4.9}$ & $\begin{array}{l}\text { Bacteroides } \\
\text { intermedius }\end{array}$ & 4 \\
\hline & & $\underline{1.2}$ & Not identified & 1 \\
\hline & B & 0 & & \\
\hline & D & 0 & & \\
\hline
\end{tabular}

LD-egg yolk agar ${ }^{18)}$ を使用して検索する lecithinase 活 性は phospholipase Cであり，ガス壊疽の原因菌である

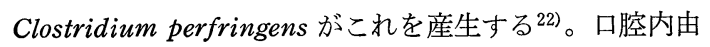
来細菌では一部のPropionibacterium acnesがこの活性を 有する ${ }^{23)}$ 。B. gingivalis や B. intermedius では lecithinase の一種である phospholipase A 活性を有する株が 報告されている24)。本実験では B. intermedius 2 菌株 に phospholipase C 活性がみられたが, B. gingivalis に はこの活性はみられなかった。

Collagenase 産生株は 4 症例から 28 株分離され, 全て が B. gingivalis であった (Table 3)。Plasmin 産生株は 26 株であり, そのうち 20 株が B. gingivalis で, 6 株が 非黒色色素産生性の Bacteroides であった (Table 3)。

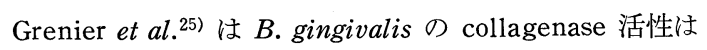
菌株間で強さが異なることを報告しており, 本実験での plasmin 活性のように, B. gingivalis の病原性の強さは, 菌株間でかなりの相違があると考えられる。

Lipase 産生株は 22 株であり, そのうち 20 株が $B$. intermedius であった17)。API ZYM を用いた結果では, lipase 産生株は, Actinomyces が優勢であった。本実験 では, B. intermedius がほとんどであり，これは lipase が作用する基質が異なるためであると考えられる。ま た, 当教室が保存している B. intermedius 37 株はすべ て LD-egg yolk agar 上における lipase 活性が陽性で あったことから, lipase 活性が B. intermedius の同定法 に利用出来ると考えられる。

本実験の結果から, lecithinase 活性と lipase 活性を 有する菌株は B. intermedius, collagenase および plasmin 産生株は B. gingivalis がそれぞれ優勢であった。
このように歯周病原細菌と考えられている B. gingivalis と B. intermedius が本実験での酵素活性の面からも主 役を演じていることが明らかになったが，前述したよう に, B. gingivalis と B. intermedius の酵素活性は菌株間 で異なる。また, これらの細菌の分布比率は被験者間で 大きく相違している。

このようなことを考光併せると, 重度歯周疾患の病因 を明らかにするためには, 長期に亘って, 臨床経過とポ ケット内細菌の変動について検討する必要がある。

\section{結 論}

6 名の重度歯周疾患患者の歯周ポケットから分離した 527 株の細菌を用いて, lecithinase, collagenase, plasmin, lipase, coagulase, $\beta$-lactamase, hyaluronidase, chondroitin sulfatase および DNase 活性について検索 した結果, 以下の成績を得た。

1. Lecithinase 産生株は 2 株検出され, 2 株とも, B. intermedius であった。本菌が分離されたポケット内で の分布比率は $2.0 \%$ であった。

2. Collagenase 産生株は, 28 株であり, いずれも， B. gingivalis であった。本菌は 4 名の患者から分離さ れ，その分布比率は 1.2 14.9\% であった。また, plas$\min$ 産生株は 26 株であり, 4 名の患者から分離された。 そのうち, 20 株は B. gingivalis であった。分布比率は $1.2 \sim 13.9 \%$ であった。

3. Lipase 産生株は 22 株検出され，19株が B. intermedius であった。

4. 他の酵素を産生する菌株は検出されなかった。 
以上の結果から，直接的な病原因子と考えられる lecithinase, collagenase, plasmin, lipase などの酵素産 生株の主体は Bacteroides であると考えられる。

\section{文献}

1) Slots, J. : Subgingival microflora and periodontal disease. J. Clin. Periodontol., $6: 351-$ 382, 1965.

2) Spiegel, C.A., Hayduk, S.E., Minah, G.E. and Krywolap, G.N. : Black-pigmented Bacteroides from clinically characterized periodontal sites. J. Periodont. Res., 14 : 376-382, 1979.

3) Crawford, A., Socransky, S.S. and Bratthall, G. : Predominant cultivable microbiota of advanced periodontitis. J. Dent. Res., 54 : Special issue $\mathrm{A}$, 97, 1975.

4) Slots, J.: The predominant cultivable microflora of advanced periodontitis. Scand. J. Dent. Res., 85 : 114-121, 1977.

5) Tanner, A.C.R., Haffer, C., Bratthall, G.T., Visconti, R.A. and Socransky, S.S. : A study of the bacteria associated with advancing periodontitis in man. J. Clin. Periodontol., $6: 278-$ 307, 1979.

6) Slots, J. : Enzymatic characterization of some oral and nonoral gram-negative bacteria with the API ZYM system. J. Clin. Microbiol., 14 : 288-294, 1981.

7) 山本綾子：口腔内 Bacteroides melaninogenicus $の$ collagenase 活性に関する研究. 歯科学報, 73 : 1166-1171, 1973.

8) Nitzan, D., Sperry, J.F. and Wilkins, T.D. : Fibrinolytic activity of oral anaerobic bacteria. Arch. Oral Biol., 23 : 465-470, 1978.

9) Fujimura, S. and Nakamura, T. : Isolation and characterization of a protease from Bacteroides gingivalis. Infect. Immun., $55:$ 716-720, 1987.

10) 内田武志, 岡本 莫 : 歯周病に打ける細菌内毒素 の役割。広大歯誌，9:1-11，1977.

11) Ingham, H.R., Sisson, P.R., Tharagonnet, D., Selkon, J.B. and Codd, A.A. : Inhibition of phagocytosis in vitro by obligate anaerobes. Lancet II (8051) : 1252-1254, 1977.

12) Okuda, K., Slots, J. and Genco, R.J. : Bacteroides gingivalis, Bacteroides asaccharolyticus and Bacteroides melaninogenicus subspecies: Cell surface morphology, and adherence to erythrocy- tes and human buccal epithelial cells. Curr. Microbiol., 6 : 7-12, 1981.

13）井下英二, 天野敦雄, 玉川裕夫, 埴岡 隆, 零石 聡, 常光 旭: Bacteroides gingivalis 381 株の菌 体外赤血球疑集素の部分精製とその性状. 日歯周 誌， $27: 807-815,1985$.

14）本城範典：歯周初期治療における Advancing periodontitis 患者の歯周ポケット内細菌叢の変化. 歯科医学, $47: 603-620,1984$.

15）井上純一, 本城範典, 山岡 昭, 前田陽規, 岩本 吉則, 福島久典, 佐川寛典 : Advancing periodontitis 患者の外科処置後における歯周ポケット 内細菌の検索. 日歯周誌, $27: 400-406,1985$.

16）井上純一：歯周初期治療による Moderate periodontitis 患者の歯周ポケット内細菌叢の変動. 日 歯周誌, $28: 484-499,1986$.

17）井上純一, 福島久典, 豊嶋ゆかり, 笹木 充, 山 本宏治, 上田雅俊, 山岡 昭, 佐川寛典 : 重度の 歯周疾患患者から分離した歯周ポケット内細菌の 酵素活性について。 日歯周誌, $30: 515-525,1988$.

18) Dowell, V.D. and George L.L. : Pathogenic members of the Genus Bacteroides, Starr, M.P. ed., The Prokaryotes Volume II, Spring-Verlag, Berlin, Heidelberg, New York, 1981, 1438.

19) 医科学研究所学友会編: 細菌学実習提要, 第 5 版, 丸善株式会社, 東京, 1977, 157.

20) Smith, R.S. and Willett, N.P. : Rapid plate method for screening hyaluronidase and chondroitin sulfatase-producing microorganisms. Appl. Microbiol., 16 : 1434-1436, 1968.

21) Jefferies, C.D., Holtman, D.F. and Guse, D.G. : Rapid method for determining the activity of microorganisms on nucleic acid. J. Bacteriol., $73: 590,1957$.

22）村田良介, 鈴木友二, 逢坂 昭, 田宮信雄, 大橋 誠, 船津 勝: タンパク毒素 (上), 256-325, 講談 社, 東京, 1972 .

23）中村 武, 藤村節夫: Propionibacterium acnes の 歯周組織破壊酵素. 日本歯科評論, $503: 137-145$, 1984.

24) Slots, J. and Genco, R.J. : Black-pigmented Bacteroides species, Capnocytophaga species, and Actinobacillus actinomycetemcomitans in human periodontal disease: Virulence factors in colonization, survival, and tissue destruction. J. Dent. Res., 63 : 412-421, 1984.

25) Grenier, D. and Mayrand, D. : Selected characteristics of pathogenic and non-pathogenic 
strains of Bacteroides gingivalis. J. Clin. Micro-

biol., 25 : 738-740, 1987.

連絡先:

大阪歯科大学細菌学教室

于 540 大阪市中央区大手前 1-5-31 